Journal of Extension Education

Vol. 29 No. 4, 2017

DOI:https: / / doi.org/10.26725/JEE.2017.4.29.5978-5983

\title{
A Study on Annual Expenditure and Income from Goat Farming in Kerala
}

\section{Bimal P.Bashir ${ }^{1}$, R. Thiruppathi Venkatachalapathy ${ }^{2}$ and Subin K.Mohan ${ }^{1}$}

\begin{abstract}
A study on goat farmers from three districts of Kerala viz., Kannur, Kozhikode and Malappuram districts was carried out to study the annual expenditure and income from goat farming under field condition in Northern Kerala. Study revealed that small flock size (16-45) got the highest net return per goat per annum. The net return worked out to be Rs. 1748, 2374, 2960, 2258 and 1602 per goat / annum, respectively. The net profit (per goat/annum) increases and reaches a maximum point and again decreases with the increase of flock sizes due to inadequate nutrition and management practices by larger goat keepers. B:C ratio also showed a similar pattern of change with flock size. Selling of goats was the major source of income followed by milk, manures and urine. In the present study, shrinking of grazing resources, lack of good quality breeding stocks improper management practices, high and labour cost were found to be the major constraints in making the goat farming more remunerative. Therefore, rearing of goat cannot sustain only on grazing resources and cut fodder and needs to switch over to systematic commercial goat farming systems via., semi-intensive / intensive system of management. Recurring cost need to be curtailed by adopting mechanization and modernization especially in large farms and also cultivating fodder and formulating and preparing concentrate in the farm itself.
\end{abstract}

Keywords:- Goat farming; Expenditure; Income; Net profit; Kerala

\section{INTRODUCTION}

Goat contributes significantly to the Indian economy, especially as a sustainable livelihood for rural farming community. The share of goats to the total milk yield and meat production in India was recorded as $3.00 \%$ and $14.25 \%$, respectively (GOI,2017). The demand for goat meat (Chevon) is progressively increasing. India possesses $18.60 \%$ (135.10 million) of world goat population and ranks first in goat milk production in world (NDDB, 2017).

1-Assistant Professor, Department of Veterinary and Animal Husbandry Extension, College of Veterinary and Animal Sciences, Pookode, Wayanad, Kerala. 2- Professor, Department of Genetics and Breeding, College of Veterinary and Animal Sciences, Mannuthy, Thrissur, Kerala 
One of the important native breeds of goat in the state of Kerala is Malabari, which is a dual purpose goat breed and the home tract of its being Northern part of Kerala (Raghavan and Raja, 2012). Land availability, high labour cost, ever shrinking of grazing land are the major constraint for farmers in the state and since goat farming can overcome these constraints easily, they have immense opportunities and potential for generating income and employment to landless, resource poor's in the state. Keeping this in view, a study was conducted to identify the expenditure and income from goat farming in Northern Kerala with the objective of assessment of rearing system followed in the area and the overall economics of goat farming in the study area.

\section{METHODOLOGY}

The study was conducted in three districts viz., Kannur, Kozhikode and Malappuram covering the northern part of Kerala during 2016-2017. The data were collected on annual expenditure and income from goat production from primary as well as secondary sources using interview schedule. Door to door survey of 373 households was carried out to find out the flock sizes, goat farming system, expenditure, income etc. in six taluks, covering 30 villages coming under the All India Co-ordinated Research Project on Goats (Malabari Units). Participatory Rural Appraisal and farmer group discussions were recorded for assessing the situation related to goat rearing in the area. The information related to selection of goats, feeding, housing, breeding, healthcare management practices along with expenditure, income, net returns etc were recorded.

The selected goat farmers were classified in to five categories based on flock size viz., Catergory I- very small (15), Category II- small (6-15), Category III-medium (16-45), Category IV-large (46-100) and Category V- very large (101 and above). The details of number of goat farmers in each category selected, land holding, flock range, average flock size, system of goat farming and Benefit : Cost ratio in different categories are given in Table. 1 .

\section{FINDINGS AND DISCUSSION}

Small owners mostly followed household level stall feeding with little bit grazing mostly in common land like roadsides, open fields etc. While large goat keepers raised their goats solely on cut grass and follow intensive or semiintensive system of rearing with 3-4 hours of grazing especially in the evening.

\section{Economics of Different Flock sizes of Goat Farming:}

Average flock size for the five category of goat farmers based on flock holding were 2.98, 9.75, 27.2, 62.1 and 163.75 respectively (Table 1$)$. The results showed a marked difference in system of goat rearing among the five categories of goat farmers studied with flock size 
Table 1.

Categorization of Goat Keepers on Flock Sizes

$(\mathrm{n}=373)$

\begin{tabular}{|c|c|c|c|c|c|}
\hline Categories & $\begin{array}{c}\text { Very small } \\
\text { (I) }\end{array}$ & $\begin{array}{c}\text { Small } \\
\text { (II) }\end{array}$ & $\begin{array}{l}\text { Medium } \\
\text { (III) }\end{array}$ & $\begin{array}{c}\text { Large } \\
\text { (IV) }\end{array}$ & $\begin{array}{c}\text { Very } \\
\text { large (V) }\end{array}$ \\
\hline $\begin{array}{l}\text { No. of goat } \\
\text { farmers }\end{array}$ & $\begin{array}{l}132 \\
(35.39 \%)\end{array}$ & $\begin{array}{l}100 \\
(26.81 \%)\end{array}$ & $\begin{array}{l}78 \\
(20.91 \%)\end{array}$ & $46(12.33)$ & $17(4.56)$ \\
\hline Land holding & $\begin{array}{l}\text { landless / } \\
\text { marginal }\end{array}$ & marginal & $\begin{array}{l}\text { small/ } \\
\text { marginal }\end{array}$ & $\begin{array}{l}\text { Large/ } \\
\text { small }\end{array}$ & Large \\
\hline Flock ranges & 1 to 5 & 6 to 15 & $16-45$ & $46-100$ & $\begin{array}{l}101 \text { and } \\
\text { above }\end{array}$ \\
\hline Average flock size & 2.98 & 9.75 & 27.2 & 62.1 & 163.75 \\
\hline $\begin{array}{l}\text { Goat farming } \\
\text { system }\end{array}$ & $\begin{array}{l}\text { household } \\
\text { rearing }\end{array}$ & $\begin{array}{l}\text { Household } \\
\text { rearing } \\
\text { / semi } \\
\text { intensive }\end{array}$ & $\begin{array}{l}\text { semi- } \\
\text { intensive }\end{array}$ & $\begin{array}{l}\text { intensive } \\
\text { / semi } \\
\text { intensive } \\
\text { system }\end{array}$ & $\begin{array}{l}\text { intensive } \\
\text { system }\end{array}$ \\
\hline $\mathrm{B}: \mathrm{C}$ ratio & 1.3 & 1.49 & 1.53 & 1.55 & 1.54 \\
\hline
\end{tabular}

ranging one to five (Very small, I) and 6-15 (Small, II); were mostly rearing their goats in the home and graze in their premises. Medium sized flock sized goat farmers (16-45, III) were following semiintensive type of rearing system. Farmers rearing goat of the flock size ranging from 46 and above (Large and very large categories) adopted intensive system of rearing, were goat are confined to the shed and cut-grass / total complete feed ration wee provided in the shed itself.

The perusal of Table 1 . revealed that more than 60.00 per cent of goat farmers studied had flock size 15 or less and they were either marginal or landless farmers who reared goats besides their home and graze in their premises. Whereas, around 18.00 per cent of goat farmers studied were keeping a flock of 46 and more goats and had small to large land holding. They followed semi-intensive to intensive system of rearing. It was also noted that one-fifth $(21.00 \%)$ of goat farmers studied had a flock size ranging from 16-45 goats had marginal or small land holding and followed semi-intensive system of rearing system which allowed daily grazing of goats for 4-6 hours in confined grazing lands.

\section{Category wise expenditure}

Annual expenditure on goat farming was estimated based on investment on feeding, depreciation on shed, labour wages and veterinary aids spend in an year. This were tabulated and depicted in Table 2. 
Table 2.

Annual expenditure

(n = 373)

\begin{tabular}{|l|l|r|r|r|r|r|}
\hline S1. & \multicolumn{1}{|c|}{ Category } & \multicolumn{1}{|c|}{$\begin{array}{c}\text { Very } \\
\text { small }\end{array}$} & Small & Medium & Large & Very large \\
\hline 1. & $\begin{array}{l}\text { Average flock sizes } \\
\text { (no.) }\end{array}$ & 2.98 & 9.75 & 27.2 & 62.1 & 163.75 \\
\hline 2. & Value of initial stock & 31020 & 137210 & 324130 & 617180 & 1146250 \\
\hline 3. & Investment on feeding & 1093 & 5412 & 10712 & 33721 & 349770 \\
\hline 4. & Depreciation on shed & 403 & 1474 & 3597 & 10942 & 51697 \\
\hline 5. & Labour wages & 112 & 507 & 1332 & 4075 & 60498.75 \\
\hline 6. & Veterinary aids & 1608 & 7393 & 15641 & 121738 & 607965.75 \\
\hline 7. & $\begin{array}{l}\text { Total variable cost (I } \\
\text { to iii) }\end{array}$ & 32628 & 144603 & 339771 & 738918 & 1754215.75 \\
\hline 8. & Gross expenditure & &
\end{tabular}

The average annual expenditure of Rs. 32,628.00, Rs. 1,44,603.00, Rs. 3,39,771.00, Rs. 7,38,918.00 and Rs. $17,54,215.75$ was incurred for category I, II, III, IV and V respectively. The major investment was found on the value of initial stock, which accounted alone for an average of 89.86 per cent of the total expenditure. The maintenance cost of goats i.e., the labour cost per year were found to be Rs. 73000/- and Rs. 146000/for Category IV and V respectively. Two full time labours required to maintain a farm with flock size between 101 to 150 . Whereas, one full time labour for category IV i.e., for flock size between 46 to 100 goats.

Among maintenance costs, highest was on feeding (74.85\%) followed by shelter $(12.72 \%)$ and veterinary aid $(12.43 \%)$. It is evident from the
Table 3. that as the flock size increased the recurring expenditure increased, because the large goat keepers were mostly follow intensive type of rearing system and require more allocation in the form of feed, labour and veterinary aid.

\section{Category wise income:}

Annual income from goat farming was estimated based on sales of goat, milk, manure and goat urine in an year. This was tabulated and depicted in Table 3.

The gross and net profit worked out to be Rs.37,838/- and Rs. 5, 210/for category I, Rs. 1,67,746/- and Rs.23,143/- for category II, Rs.4,20,294/and Rs. 80,523/- for category III, Rs. $8,79,165 /-$ and Rs. 1,40,247/- for category IV and Rs. 20,16,620/- and Rs. 
Table 3.

Annual Income

$(n=373)$

\begin{tabular}{|c|c|c|c|c|c|c|}
\hline $\begin{array}{l}\text { S1. } \\
\text { No. }\end{array}$ & Category & $\begin{array}{c}\text { Very } \\
\text { Small (I) }\end{array}$ & Small (II) & $\begin{array}{l}\text { Medium } \\
\text { (III) }\end{array}$ & $\begin{array}{c}\text { Large } \\
\text { (IV) }\end{array}$ & $\begin{array}{c}\text { Very large } \\
\text { (V) }\end{array}$ \\
\hline 1. & $\begin{array}{l}\text { Value of existing } \\
\text { stock }\end{array}$ & 22173 & 96910 & 189140 & 434700 & 1162000 \\
\hline 2. & Sale of goats & 14155 & 62155 & 141723 & 296300 & 576180 \\
\hline 3. & Sale of milk & 0 & 4317 & 50640 & 76650 & 120450 \\
\hline 4. & Sale of manure & 1510 & 3321 & 35780 & 61408 & 133590 \\
\hline 5. & Sale of urine & 0 & 508 & 3011 & 10107 & 24400 \\
\hline 6. & $\begin{array}{l}\text { Annual return (I to } \\
\text { IV) }\end{array}$ & 15665 & 70836 & 231154 & 444465 & 854620 \\
\hline 7. & Gross income & 37838 & 167746 & 420294 & 879165 & 2016620 \\
\hline 8. & Net income & 5210 & 23143 & 80523 & 140247 & 262404.25 \\
\hline 9. & Net profit / goat & 1748.32 & 2373.64 & 2960.40 & 2258.41 & 1602.47 \\
\hline 10. & B:C Ratio & 1.3 & 1.49 & 1.53 & 1.55 & 1.54 \\
\hline
\end{tabular}

2,62,404/- for category V, respectively. Other than existing stock value, major source of income was from the sales of goats $(71.90 \%)$ followed by milk (15.10\%), manures (9.20\%) and urine (3.80\%). The overall average value of existing stock over a year remained constant as compared to the initial stock value, after the selling of 71.57 per cent of individuals. The annual net profit per goat was highest in category III (Rs. 2960.40), followed by Category II (Rs. 2373.64), Category IV (Rs.2258.41), Category I (Rs. 1748.32) and Category V (Rs. 1602.47) with an overall average of Rs. 2188.68 respectively.

The annual gross and net income per house hold/ goat farm appreciably increased with the increase of flock size but net return per goat showed an increasing trend initially and reaching a peak level at the medium level of flock size (Category III) and showed a decreasing trend afterwards. As the flock size increases above 60, additional labour, veterinary aid and more care is needed under farm level. Most of goat farmers rearing goats above 100 were maintaining goat in either semi-intensive or intensive system and their recurring cost on feed, fodder, labour, veterinary aid etc. were more compared to household goat rearing. Moreover, farmers found it difficult to provide individual attention and care when the flock size of their farms goes beyond 100. Besides that, high incidence of diseases, ecto and endo parasites infestation were common in large farms. This might be due to lack of skilled labour and high labour 
cost forcing the farmers to maintain farm with limited labour for conducting routine farm activites like deworming, vaccination etc. On the other hand, small owners fed goats mainly on cut grass and allowed grazing, fed kitchen waste, cultivate fodder and took better care of their flock and achieved higher net returns.

\section{CONCLUSION}

This study on economics of goat rearing, covering 373 goat farmers from three districts of Northern Kerala based on different flock sizes showed that apart from providing a subsidiary income to the families, rearing of goats, acted as a source of protein supplement to the family members of the household in the form of milk and meat in the study area.

The shrinking of grazing resources, lack of good quality breeding stocks and improper management practices, high labour cost were found to be the major constraints in making the goat farming more remunerative. Therefore, goat farms with large flock size needs to switch over to systematic commercial goat farming systems via., semi-intensive / intensive system of management. Recurring cost need to be curtailed by adopting mechanization and modernization especially in large farms and also cultivating fodder and formulating balanced goat feed and preparing concentrate in the farm itself. In large farms, systematic management of sales need to be adopted and they must replace 10 to 15 percent of parent stock with the new once. Unhealthy and weak goats needed to be sold before the rainy season in order to avoid heavy parasitic load and high mortality of kids during adverse climatic condition.

\section{REFERENCES}

Bashir, B.P. \& Venkatachalapathy, T.R. (2016). Economics of Household Malabari Goat Farming in Northern region of Kerala. International Journal of Agricultural Science Research. 6:529-534.

GOI.( 2017). Basic Animal Husbandry Statistics. Ministry of Agriculture, Govt. of India.

NDDB. (2017). Retrieved from http:// www.nddb.org/information/stats/ outputvalue

Raghavan, K.C \& Raja, T.V. (2012). Analysis on the Socioeconomic Status of the Goat Farmers of Malabar Regionof Kerala. Veterinary Research 5: 74-76. 